ORIGINAL ARTICLE

\title{
PREDICTORS OF IN-HOSPITAL LENGTH OF STAY IN NSTEMI PATIENTS
}

\author{
Ahmad Handayani ${ }^{*}$, Andika Sitepu ${ }^{2}$, Faisal Habib ${ }^{3}$ \\ 1 Cardiology Division, Faculty of Medicine, Muhammadiyah University of Sumatera Utara \\ 2 Cardiology Department, Faculty of Medicine, University of Sumatera Utara; Grandmed \\ Lubukpakam General Hospital \\ 3Cardiology Division, Faculty of Medicine, Muhammadiyah University of Sumatera Utara, Aceh \\ Tamiang General Public Hospital \\ *Corresponding author: ahmadhandayani@umsu.ac.id
}

\begin{abstract}
As our population grows older, the rate of NSTEMI patients is rising. Risk stratification is an important process for patients with Non-ST Elevation Myocardial Infarction (NSTEMI). Global Registry of Acute Coronary Events (GRACE) scores in the best to predict mortality and myocardial infarction in NSTEMI Patients. On the other hand, NSTEMI Patients trends to be older with more co-morbidity. In this scenario, we need to predict the length of stay as it correlates with the patient's prognostic and cost. This study aims to analyze factors influencing the in-hospital length of stay in survivor NSTEMI Patients in four different hospitals (Adam Malik Medan National General Hospital, Pirngadi Medan General Hospital, Grandmed Lubuk Pakam General Hospital, and Aceh Tamiang Public General Hospital). This was an observational study with prospective design conducted on 44 patients in four different hospitals from March to May 2017. We only included the patients that discharged alive from the hospital. Statistical analysis was performed to assess the routine clinical and laboratory variables relations with the length of stay. Prolong length of stay was defined as more than 5 days. As mentioned in the previous study, older age, heart failure will prolong the length of stay. The limitations of this study were we didn't analyze the effect of revascularization, the co-morbidities, and the method of patient's payment. We should use GRACE and TIMI risk score routinely, optimizing therapy for heart failure and giving special attention to elderly patients in NSTEMI Patients.
\end{abstract}

Keywords: NSTEMI, GRACE, Length of Stay 


\section{INTRODUCTION}

The cardiovascular disease ranks the first cause of death worldwide. As many as 17.3 million people are estimated to have died of cardiovascular disease in 2008. Of all of these deaths, as many as $80 \%$ are due to heart attacks and strokes, and three-quarters of these occur in countries with a lower-middle economy. ${ }^{1}$ These complications due to cardiovascular disease also have a bad economic and social impact especially on the middle to lower economic population. ${ }^{2}$ This certainly requires optimal prevention and management strategies.

Coronary heart disease (CHD) in Indonesia ranks third cause of death after stroke and diabetes mellitus (DM) in the noncommunicable disease group in the age range 45-54 years in urban populations, ranked fourth after tuberculosis, stroke, and hypertension in rural populations in Indonesia according to the results of basic health research in $2007 .^{3}$

Based on history, physical examination, electrocardiogram (EKG), and cardiac enzyme examination, acute coronary syndrome (ACS) are divided into ST-segment-elevation myocardial infarction (STEMI), non-ST-segment elevation myocardial infarction (NSTEMI), and unstable angina pectoris (UAP). NSTEMI and UAP are classified into non-ST-segment elevation acute coronary syndromes (NSTE-ACS). ${ }^{4}$

The prevalence of NSTEACS covers about 70 percent of the incidence of ACS with the characteristics of patients who are Buletin Farmatera

Fakultas Kedokteran (FK)

Universitas Muhammadiyah Sumatera Utara (UMSU)

http://jurnal.umsu.ac.id/index.php/buletin_farmatera usually older and have more comorbidities. Unlike patients with STEMI who receive more uniform therapeutic guidelines namely early revascularization, patients with NSTE-ACS undergo a therapeutic method more varied with the severity of coronary artery stenosis which is very varied. Even though management guidelines are available for the management of NSTE-ACS, there are still therapeutic behaviors that are inconsistent in the use of invasive and conservative strategies that illustrate the uncertainty in the initial evaluation and management of patients. NSTEMI itself has disease complications and coronary artery severity worse than UAP. ${ }^{4,5}$

Therefore early identification of complications from NSTEMI is important to do to prevent complications. This can then help in providing management strategy recommendations and improving post-treatment outcomes. ${ }^{6}$

Several ways of risk stratification have been developed and validated for ACS. Some of the most commonly used risk stratifications are the TIMI and GRACE scores. The TIMI score resulted from the TIMI $11 \mathrm{~b}$ study and was validated in several trials such as TACTICS-TIMI $18 .^{7}$ The disadvantage of the TIMI score is its inability to discriminate risk in more detail. The GRACE score is the most recent but is more complicated and requires the use of a computer application in its calculation. ${ }^{8}$ One score that is not very well known is the PURSUIT (Platelet glycoprotein IIb/IIIa score in Unstable angina: Receptor Suppression Using 
Integrilin Therapy). In a study by Goncalves et al who examined the use of GRACE, TIMI, and PURSUIT scores in the same population in a health center in 460 patients. The results show that the GRACE score is the best in assessing the risk of death or myocardial infarction within 1 year. ${ }^{9}$ This is in line with the research of Aragam et al who saw that the discrimination power of GRACE scores was better than TIMI. $^{10}$ The parameters assessed on the GRACE score and their interpretation are shown in tables 1 and 2 .

Life expectancy is increasing, causing our population to grow older. This is in line with the incidence of acute myocardial infarction non-ST elevation segments (NSTEMI). It must be remembered also that NSTEMI patients tend to be older with more comorbidities. With the characteristics of older patients and more comorbidities, NSTEMI patients need special attention. One of them is to predict the length of stay. ${ }^{13}$

The purpose of this study was to analyze the factors that influence the length of stay in NSTEMI patients who stayed in four different hospitals (Haji Adam Malik General Hospital, Medan Pirngadi General Hospital, Grandmed Lubuk Pakam General Hospital, and Aceh Tamiang General Hospital).
Table 1. GRACE Scores ${ }^{11,12}$

\begin{tabular}{|c|c|}
\hline Prediktor & Skor \\
\hline \multicolumn{2}{|l|}{ Usia dalam tahun } \\
\hline$<40$ & 0 \\
\hline $40-49$ & 18 \\
\hline 50.59 & 36 \\
\hline 60.69 & 55 \\
\hline $70-79$ & 73 \\
\hline 80 & 91 \\
\hline \multicolumn{2}{|c|}{ Laju denyut jantung (kali per menit) } \\
\hline$<70$ & 0 \\
\hline $70-89$ & 7 \\
\hline $90-109$ & 13 \\
\hline 110-149 & 23 \\
\hline $150-199$ & 36 \\
\hline$>200$ & 46 \\
\hline \multicolumn{2}{|l|}{ Tekanan darah sistolik (mmHg) } \\
\hline$<80$ & 63 \\
\hline $80-99$ & 58 \\
\hline $100-119$ & 47 \\
\hline $120-139$ & 37 \\
\hline $140-159$ & 26 \\
\hline $160-199$ & 11 \\
\hline$>200$ & 0 \\
\hline \multicolumn{2}{|l|}{ Kreatinin (umo/L) } \\
\hline $0-34$ & 2 \\
\hline $35-70$ & 5 \\
\hline $71-105$ & 8 \\
\hline $106-140$ & 11 \\
\hline $141 \cdot 176$ & 14 \\
\hline $177-353$ & 23 \\
\hline$\geq 354$ & 31 \\
\hline \multicolumn{2}{|l|}{ Gagal jantung berdasarkan Killip } \\
\hline I & 0 \\
\hline II & 21 \\
\hline III & 43 \\
\hline IV & 64 \\
\hline Henti jantung saat tiba di RS & 43 \\
\hline Peningkatan marka jantung & 15 \\
\hline Deviasi segmen ST & 30 \\
\hline
\end{tabular}

Table 2. GRACE Scores Interpretations ${ }^{11,12}$

\begin{tabular}{|l|l|l|l|}
\hline \multicolumn{2}{|c|}{ Predilktor Kematian di RS } & \multicolumn{2}{c|}{ Prediliktor Kematian 6 bulan } \\
\hline Skor & Risiko & Skor & Risiko \\
\hline$\leq 108$ & $<1 \%$ & $\leq 88$ & Rendah $(3 \%)$ \\
\hline $109-140$ & $1-3 \%$ & $89-118$ & Sedang $(3-8 \%)$ \\
\hline$>140$ & $>3 \%$ & $>118$ & Tinggi $(>8 \%)$ \\
\hline
\end{tabular}




\section{METHODS}

This research is a prospective observational design that was carried out from March 1, 2017 to May 15, 2017, in four hospitals in three different districts/cities, namely the Haji Adam Malik General Hospital, Pirngadi General Hospital Medan, Grandmed Lubuk Hospital Pakam, and the Aceh Tamiang Regional General Hospital.

The sample collection is using consecutive sampling. Researchers only observe and record the data found in the patient. The entire examination is carried out by the doctor on duty, both the doctor on duty and the cardiologist.

The inclusion criteria were patients with a NSTEMI diagnosis based on the diagnosis criteria of PERKI that is if there was a complaint of acute angina accompanied by a significant increase in cardiac enzymes (CKMB or troponin) without any persistent ST-segment elevation in two adjacent leads and without a left branch beam block. ${ }^{4}$ Exclusion criteria were patients with: ${ }^{14}$

1. Patients with 2nd and 3rd degree AV block

2. Patients who arrive with cardiogenic shock (Killip IV)

3. Patients who die during treatment by all causes

4. Patients with several other conditions that are the main cause of an increase in cardiac enzymes. These conditions include:
a. Tachyarrhythmias
b. Decompensated heart failure is not due to ACS
c. Emergency hypertension

d. Critical illnesses include sepsis, non-cardiogenic shock and burns

e. Myocarditis

f. Tako-Tsubo cardiomyopathy

g. Aortic stenosis

h. Pulmonary embolism

i. Acute kidney disorder

j. Coronary spasm

k. Acute neurological events (stroke, subarachnoid hemorrhage)

1. Heart, hypo and hyperthyroid surgery procedures

m. Connective tissue diseases (scleroderma, hemochromatosis)

n. Rhabdomyolysis.

The flow of research can be seen in Figure 1.

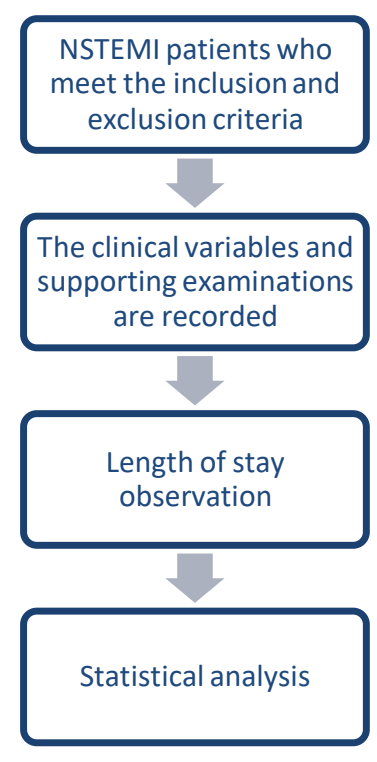

Figure 1. Research Flow

Statistical analysis was performed to assess the relationship between various variables and routine laboratories with the length of stay. 
The independent variables analyzed were age, sex, major complaints, onset of primary complaints, body mass index, pain scale, history of previous illnesses (hypertension, diabetes mellitus, CHD, and dyslipidemia), family history of coronary heart disease, smoking history, history previous drugs (beta-blockers and angiotensin-converting enzyme inhibitors), use of beta-blockers and angiotensin-converting enzyme inhibitors during treatment, TIMI score, GRACE score, Killip classification, simple hemodynamic parameters (systolic blood pressure, diastolic blood pressure, heart rate, mean blood pressure, shock index, and modified shock index), simple ECG parameters (rhythm, STsegment depression, presence of left ventricular hypertrophy, and ventricular extrasystole), laboratory parameters (hemoglobin, leukocytes, platelets, blood sugar levels, urea, creatinine, and glomerular filtration rate), the presence of cardiomegaly based on chest x-ray examination, and there are bleeding during treatment.

Statistically, a significant difference was defined as a value of $\mathrm{p}<0.05$. $^{15}$

Categorical variables are represented by the number or frequency (n) and percentage (\%). Numerical variables are presented with a mean (average) and standard deviations for normally distributed data, while data that are not normally distributed using a median (middle value) with minimum and maximum values.. ${ }^{15}$
Test for normality in all research subjects using Shapiro Wilk (n <50). In numerical variables, a two-sample Independent Student's ttest was carried out on normally distributed data and the Mann Whitney $U$ test if the data were not normally distributed. In the categorical variable, the analysis test is done using chi-squared or fisher test. $^{15}$

Receiving operator characteristic (ROC) curve analysis is performed to determine the cut length value of the length of stay. ${ }^{15}$

\section{RESULTS}

The total samples collected were 49 people. A total of 16 samples came from the Pirngadi Hospital in Medan, 14 people from the Haji Adam Malik Hospital in Medan, 11 people from the Aceh Tamiang General Hospital, and 8 samples from the Grand Medistra Lubuk Pakam Hospital. Five people were excluded because they died during treatment so that the final sample numbered 44 people.

The length of stay is divided into the usual length of stay and the length of stay that is defined as more than 5 days based on the results of the ROC curve analysis test.

Data analysis of the relationship between clinical factors and supporting examinations on length of stay can be seen in Table 3 . Variables that looked significantly different were age, history of suffering from hypertension, TIMI score, GRACE score, and the presence of cardiomegaly during treatment. 
Table 3. Analysis of The Predictive Factors for Length of Stay

\begin{tabular}{|c|c|c|c|}
\hline Variable & $\begin{array}{c}\text { Without Lengthening } \\
\text { of Stay ( } \leq 5 \text { days) (19 } \\
\text { Patients) }\end{array}$ & 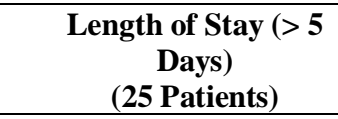 & P-value \\
\hline \multicolumn{4}{|l|}{ Early Clinical Factors } \\
\hline Age & $53,4 \pm 1,4$ & $60,4 \pm 1,5$ & $0,004 *$ \\
\hline \multicolumn{4}{|l|}{ Gender } \\
\hline Male & $16(84 \%)$ & $17(68 \%)$ & $0,191 * *$ \\
\hline Female & $3(16 \%)$ & $8(32 \%)$ & \\
\hline \multicolumn{4}{|l|}{ Chief complaint } \\
\hline Chest Pain/Epigastric pain & $15(79 \%)$ & $16(64 \%)$ & $0,282 * *$ \\
\hline Shortness of breath & $4(21 \%)$ & $9(36 \%)$ & \\
\hline Onset of chief complaint (hour) & $16(2-336)$ & $12(0-120)$ & $0,312 * * *$ \\
\hline Pain scale (numeric rating scale) & $4(1-8)$ & $2(1-8)$ & $0,435 * * *$ \\
\hline Smoking history & $12(63 \%)$ & $14(56 \%)$ & $0,632 * *$ \\
\hline Hipertension history & $9(47 \%)$ & $20(80 \%)$ & $0,024 * *$ \\
\hline Diabetes history & $7(37 \%)$ & $8(32 \%)$ & $0,737 * *$ \\
\hline CHD history & $2(10,5 \%)$ & $6(24 \%)$ & $0,498 * *$ \\
\hline Dyslipidemia history & $4(21 \%)$ & $8(32 \%)$ & $0,419 * *$ \\
\hline $\begin{array}{l}\text { Family history with premature } \\
\text { CHD }\end{array}$ & $2(10,5 \%)$ & $2(8 \%)$ & $0,419 * *$ \\
\hline Body Mass Index & $24,4 \pm 2,9$ & $24,9 \pm 2,7$ & $0,534 *$ \\
\hline \multicolumn{4}{|l|}{ Factors of Drug Use } \\
\hline Beta-blocker usage history & 0 & $2(8 \%)$ & $0,498 * *$ \\
\hline $\begin{array}{l}\text { Use of beta-blockers within } 24 \\
\text { hours of treatment }\end{array}$ & $13(68 \%)$ & $16(64 \%)$ & $0,759 * *$ \\
\hline $\begin{array}{l}\text { Use of angiotensin-converting } \\
\text { enzyme inhibitors within } 24 \text { hours } \\
\text { of treatment }\end{array}$ & $13(68 \%)$ & $17(68 \%)$ & $0,976 * *$ \\
\hline \multicolumn{4}{|l|}{ Prediction score for prognosis } \\
\hline TIMI score & $3(1-5)$ & $3(1-6)$ & $0,043 * * *$ \\
\hline GRACE score & $92(62-168)$ & $123(73-160)$ & $0,030 * * *$ \\
\hline \multicolumn{4}{|l|}{ Hemodynamic Factor } \\
\hline Systolic blood pressure & $139 \pm 25,7$ & $140 \pm 34$ & $0,930 *$ \\
\hline Diastolic blood pressure & $80(26-100)$ & $90(40-124)$ & $0,278 * * *$ \\
\hline Heart rate & $86 \pm 24,0$ & $93 \pm 22,7$ & $0,362 * * *$ \\
\hline Average blood pressure & $101 \pm 13,9$ & $106 \pm 21,0$ & $0,419 * * *$ \\
\hline $\begin{array}{l}\text { Shock index (heart rate/systolic } \\
\text { blood pressure) }\end{array}$ & $0,60(0,32-1,2)$ & $0,68(0,36-1,2)$ & $0,255 * * *$ \\
\hline \multicolumn{4}{|l|}{$\begin{array}{l}\text { Supporting examination } \\
\text { factors }\end{array}$} \\
\hline $\begin{array}{l}\text { Atrial fibrillation on initial } \\
\text { ECG examination }\end{array}$ & $1(5 \%)$ & $2(8 \%)$ & $0,684^{* *}$ \\
\hline $\begin{array}{l}\text { ST segment deviation on } \\
\text { initial ECG examination }\end{array}$ & $10(53 \%)$ & $15(75 \%)$ & $0,427 * *$ \\
\hline Hemoglobin $(\mathrm{mg} / \mathrm{dL})$ & $13,4 \pm 1,7$ & $12,8 \pm 1,8$ & $0,302^{*}$ \\
\hline Leukocytes $\left(/ \mathrm{mm}^{3)}\right.$ & $9.823 \pm 3.543$ & $11.209 \pm 3.936$ & $0,234 *$ \\
\hline Plateletes $\left(/ \mathrm{mm}^{3}\right)$ & $259.684 \pm 39.102$ & $274.560 \pm 41.930$ & $0,549 *$ \\
\hline $\begin{array}{lll}\text { Blood } & \text { glucose } & \text { level } \\
(\mathrm{mg} / \mathrm{dL}) & & \\
\end{array}$ & $124(90-417)$ & $102(78-527)$ & 0,213 \\
\hline Ureum $(\mathrm{mg} / \mathrm{dL})$ & $34(11-125)$ & $39(17-235)$ & $0,214 * * *$ \\
\hline Creatinin $(\mathrm{mg} / \mathrm{dL})$ & $1,12(0,3-4,57)$ & $1,34(0,71-2,90)$ & $0,218 * * *$ \\
\hline $\begin{array}{l}\text { Glomerulus filtration rate } \\
\left(\mathrm{mL} / \mathrm{min} / 1.73 \mathrm{~m}^{2}\right)\end{array}$ & $65,5(14-252)$ & $63,3(15-102)$ & $0,241 * * *$ \\
\hline $\begin{array}{l}\text { Cardiomegaly on chest } \mathrm{x}- \\
\text { ray examination }\end{array}$ & $12(63 \%)$ & $23(92 \%)$ & $0,024 * *$ \\
\hline
\end{tabular}




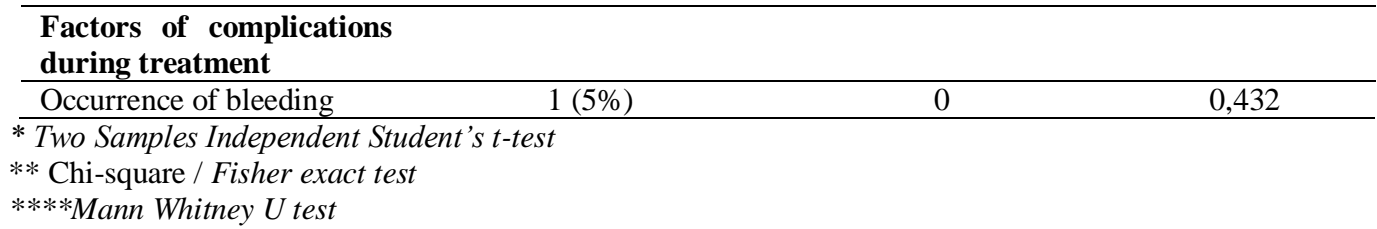

\section{DISCUSSION}

In the era of National Health Coverage in Indonesia, it is very important to control the quality and cost of health services. As mentioned in previous studies, older age and heart failure will prolong the length of stay. ${ }^{13}$

Older age shows an increased length of stay. This is due to the age factor itself reduces the body's physiological ability in the healing process. The age factor itself is included in the GRACE and TIMI scores. This shows that age is consistently a factor that affects the prognosis of patients.

GRACE and TIMI scores were proven to be able to predict the length of stay in this study. Calculation of this score becomes a tool for clinicians in stratifying risk to patients. With an increase in scores, the clinician needs to pay special attention to patient care.

The presence of cardiomegaly on chest x-ray examination is also a predictive factor. Cardiomegaly is associated with the presence of heart failure in patients in line with previous studies that showed the same thing. This is supported by the results of this study which show that the history of suffering from hypertension affects the length of stay. The limitation of this study is that we did not analyze the effects of revascularization, comorbidities, and patient payment methods. Some patients were discharged and then electrocuted revascularization. patient care. Likewise, with the patient financing method, we do not take notes. As it is known that self-financing can be a confounding factor that affects the length of stay.

\section{CONCLUSIONS}

Routine use of GRACE and TIMI risk scores, optimization of therapy for heart failure and special attention for elderly patients and hypertensive patients in NSTEMI patients are expected to reduce the length of stay and improve patient outcomes.

\section{REFERENCES}

1. World Health Organization. 2014. Global Health Estimates: Deaths by Cause, Age, Sex And Country, 20002012. Geneva: World Health Organization.

2. World Health Organization. 2016. HEART: Technical Package for Cardiovascular Disease Management in Primary Health Care. Publication Data, Geneva: World Health Organization.

3. Departemen Kesehatan Republik Indonesia. 2008. Riset Kesehatan Dasar. Jakarta: Badan Penelitian dan Pengembangan Departemen 
Kesehatan Republik Indonesia.

4. Irmalita, Juzar DA, Andrianto, Setianto BY, Tobing DPL, Firman D, et al. 2015. Pedoman Tatalaksana Sindrom Koroner Akut. Edisi Ketiga. Jakarta: Perhimpunan Dokter Spesialis Kardiovaskular Indonesia.

5. Chang H, Min JK, Rao SV, Patel MR, Simonetti OP, Ambrosio G, et al. 2012. "Non-ST-Segment Elevation Acute Coronary Syndromes: Targeted Imaging to Refine Upstream Risk

Stratification." Circulation Cardiovascular Imaging 5: 536-546.

6. Amsterdam EA, Wenger NK, Brindis RG, Casey Jr. DE, Ganiats TG, Holmes Jr. DE, et al. 2014. "2014 AHA/ACC Guideline for the Management of Patients With Non-ST-Elevation Acute Coronary Syndromes: Executive Summary." Journal of the American College of Cardiology.

7. Antman EM, Cohen M, Bernink PJ, McCabe $\mathrm{CH}$, Horacek T, Papuchis G, et al. 2000. "The TIMI risk score for unstable angina/non-st elevation MI: a method for prognostication and therapeutic decision making." JAMA 284: 835-842.

8. Granger $\mathrm{CB}$, Goldberg $\mathrm{RJ}$, Dabbous O, Pieper KS, Eagle KA, Cannon CP, et al. 2003. "Predictors of hospital mortality in the global registry of acute coronary events." Arch Intern Med 163.

9. de Araujo Gonçalves P, Ferreira J, Aguiar C, SeabraGomes R. 2005. "TIMI, PURSUIT, and GRACE risk scores: sustained prognostic value and interaction with revascularization in NSTEACS." European Heart Journal 26: 865-72.

10. Aragam KG, Tamhane UU, Kline-Rogers E, Li J, Fox KA, Goodman SG, et al. 2009. "Does simplicity compromise accuracy in ACS risk prediction? A retrospective analysis of the TIMI and GRACE risk scores." PLoS One 4: e7947.

11. Fox K, Ford I, Steg PG, Tendera M, Ferrari R. 2008. "Ivabradine for Patients with Stable Coronary Artery Disease and Left-Ventricular Systolic Dysfunction (BEAUTIFUL): A Randomised, Double-Blind, Placebo-Controlled Trial." Lancet 372: 807-816.

12. Hamm CW, Bassand JP, Agewall S, Bax J, Boersma E, Bueno H, et al. 2011. "ESC guidelines for the management of acute coronary syndromes in patients presenting without persistent ST-segment elevation." European Heart Journal 32: 2999-3054. doi:doi:10.1093/eurheartj/ehr 23.

13. Vavelle JP, Lopes RD, Chen AY, Newby LK, Wang TY, Shah BR, et al. 2012. Identifying Factors that 
Influence Hospital Length of Stay in Patients with Non-STsegment Elevation Myocardial Infarction: Insights from the Acute Coronary Treatment Intervention Outcomes Network Registry®-Get With The Guidelines. Am J Med 125

(11).doi:10.1016/j.amjmed.20 12.04.038.

14. Roffi M, Patrono C, Collet JP, Valgimigli M, Mueller C,
Andreotti F, et al. 2015. "2015 ESC guidelines for the management of acute coronary syndromes in patients presenting without persistent ST-segment elevation." European Heart Journal.

15. Dahlan, MS. 2005. Statistik Untuk Kedokteran dan Kesehatan. Jakarta: Penerbit Salemba Medika. 